\title{
Canadian Institute of Forestry/Institut forestier du Canada Brief to the Canadian Council of Forest Ministers (CCFM) 1992
}

\author{
Forest Land Tenure, Sustainable Development, Silviculture Funding \\ and Industrial Wood Supply
}

The vast majority of Canada's forest land is in public ownership.

Provincial governments have responsibility for the management of these lands.

The public is demanding integrated forest resource management, popularly expressed as sustainable forest development.

Governments are poorly equipped to run and carry out forest management and woodlands operations to supply fibre to industry at competitive prices.

Today's pressures are for governments to withdraw from business as much as possible and to regulate less, but do it better.

During the past 150 years, Canadians have tried many combinations of government and industry responsibility for forest management and woodlands operations.

Some have worked better than others, but none have consistently delivered good integrated management of public forest lands.

The demands of the times requires government to reconsider the array of services provided, their costs and the type of forest land management that is now required by the complex dynamics of public opinion, the global market place and a world growing more conscious of the value of nature.

How can these requirements best be met?

\section{Some Things are Unlikely to Change}

1. Provincial governments will retain legislated responsibility for management of publicly owned forest lands.

2. Public ownership of the majority of the country's forest lands.

3. The requirement that these lands and their resources be managed sustainably.

4. The absence of a free and open market place for raw wood in most of the country due to the preponderance of public ownership of forest land.
5 . The forest industry will continue to be privately owned and make an important contribution to the wealth of the nation.

6. Industry will continue to need a secure and competitively priced wood supply.

7. Many communities will continue their economic dependence on the forest.

8. World demand for forest products will continue to increase. Both processing and products must adapt to the changing needs of society.

9. Property rights and economic instruments will offer powerful tools to shape corporate actions. Stability generates confidence and investment.

10. Pressures to protect nature will grow and will increasingly be woven into the rules which regulate the global market place.

The nub of the problem is the interface between public landlords and private users.

How can we structure forest land management agreements between government and industry to meet the needs of our times?

\section{Tenure}

At this interface of public landlords and private users is the tenure system - the leases, licenses and permits that articulate the arrangements by which timber companies obtain access to Crown timber. These contractual undertakings are crucial for silviculture. They allocate responsibilities between the Crown and licensees, they govern incentives and disincentives to enhance timber growth, and they fix financial obligations. As soon as one begins to analyse the problems of organizing silviculture, one quickly runs up against the tenure system. (P. Pearse - Silviculture Conference - 1991)

\section{What are our objectives?}

1. Management of the forest landscape and forest ecosystems that is sustainable.

2. Protection of special values.

3. Woodlands operations that conform to plans derived from a process of integrated forest management with public involvement.

4. Reforestation of all logged areas to maintain forest productivity.

5. Intensive silviculture where it makes sense for economic or other specific reasons.

We need tenure arrangements that will help us to meet these objectives. Three systems all based on agreements to manage specific areas of forest land are outlined on the following pages.

\section{Forest Land Lease}

We may not be able to convert forest land to private ownership, but we can lease the land to the private sector for annual payments based on the productivity of the land.

The conditions of the lease can effectively describe the quality of management to be practiced and the volume and type of forest to be maintained on the land.

The annual fees can be based on the economic value of the wood produced, as well as on some or all of the other resource values derived from the leased area.

\section{Sale of Timber and Forest Land Lease}

New Zealand has recently sold parcels of their forest estate to industrial investors.

The forest consisted of softwood plantations of varying ages growing on publicly owned land.

The trees were sold by tender as a growing crop.

The land was not sold. The land was leased at market rates for periods of not less that 35 years (one rotation) with a provision for annual extensions.

This provided the government with sums of capital in return for the trees and steady income from the lease of the land. 
The industrial investors own the wood and have secure lease-hold rights to the productive capacity of the land for periods long enough to enjoy the benefits of all expenditures on silviculture.

Only 500,000 Ha. of forest was sold.

The purpose of the sale and purchase, was timber production with safeguards for special sites and water quality.

No complex integrated forest resource management conditions were required, but they could be included to adapt this tenure system to the situation in Canada.

\section{Area-based Forest Management Agreement}

Our standard forest management agreement based on a specific area with payment for the volume cut each year, can be adapted to meet present needs.

R. Dobell suggests implementation of the following changes:

- Maintain the basic social value of public ownership of land;

- Describe the quality of management to be practiced and the forest to be maintained on the land;

- Develop and implement economic instruments to delegate responsibility for management and silviculture;

- Tenure arrangements must duplicate all the incentives of private ownership except title to the land;

- Implement a predictable and stable fee structure;

- Audit performance;

- Provide equitable opportunities to respond to public needs and changing social values.

\section{The Need for Change}

Forest management in Canada is mired in inflexible institutions. We must understand the requirements of the new industrial economic environment in which we operate.

Old methods will not suffice in this new situation.

We must take the risks required to implement new tenure systems so that our companies may have the means to carryout strategic planning and attract capital to build and modernize plants.

Our present approach to tenure characterized by frequent policy changes and broken promises is a significant feature in the inhospitable investment climate that is forcing a contraction of the forest industry in Canada.

\section{CIF/IFC Gold Medal Award}

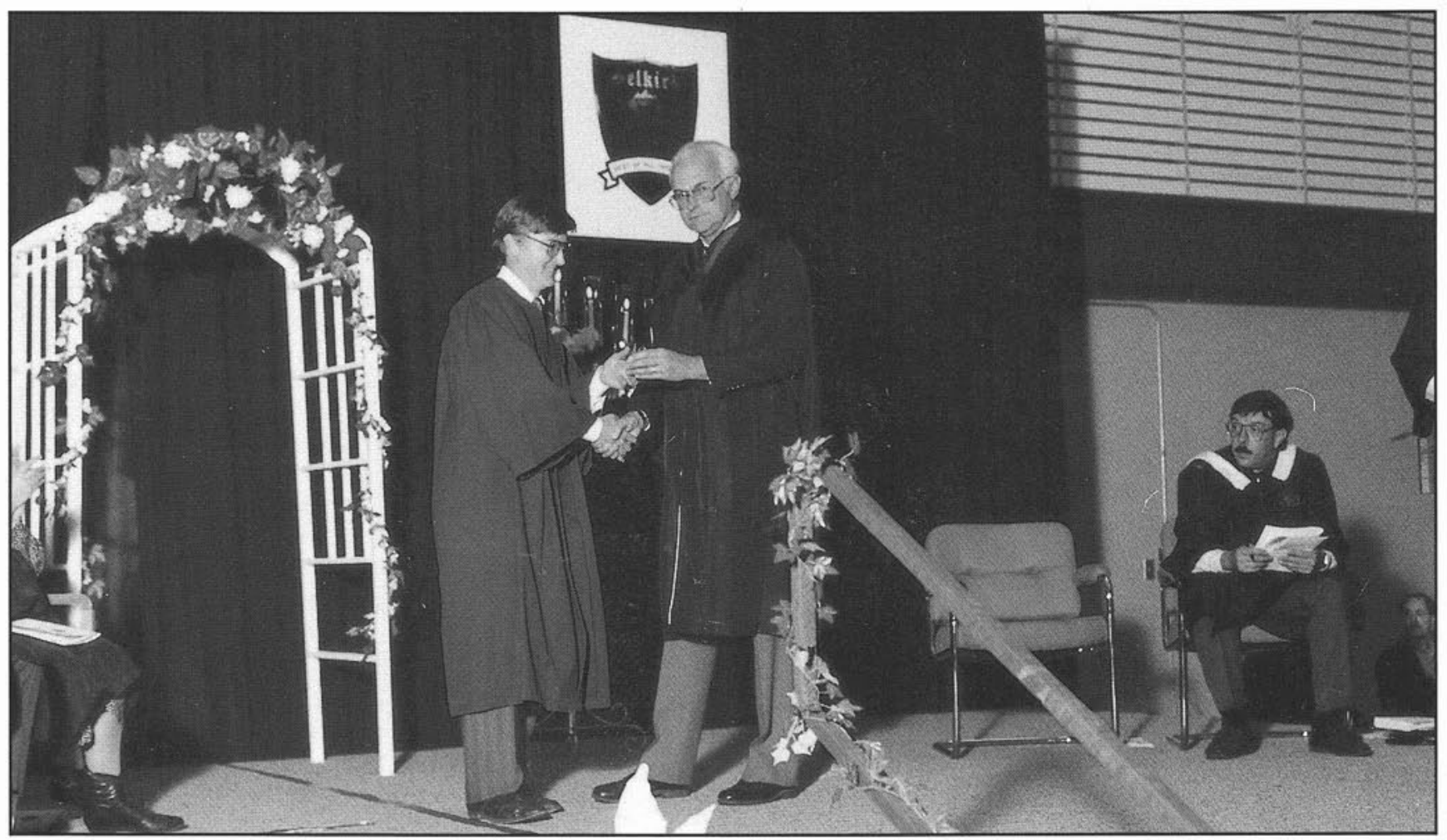

Robert Briercliffe, a second year forestry student at Selkirk College, Castlegar, BC, receives the CIF Gold Medal Award from John Adams, Department Head, Environmental Science and Technology. 